\title{
Skola inför rätta: Tolkning och användning av skolhistoria i samtidens debatt om framtidens samhälle och skola
}

\author{
Johan Samuelsson
}

\begin{abstract}
School on Trial: Interpretation and Use of School History in Contemporary Debate About the Future of Society and School. This article centres on how education and the Swedish School Commission as an historical phenomenon become resources in the discussion on how society and education should be developed. Three authors' texts on the School Commission are analysed based on narrative history theory, which engages in how history is used to legitimise political change. Education and the School Commission are inscribed in a national narrative of decline. The 1946 Commission is blamed for the perceived problems in present society and education, allegedly having caused a lack of focus on nationalism, morals and knowledge in Sweden. To change society, the message is, education must learn from the historical mistake of the Commission and invest in knowledge and nationalism. The narrative plot is reminiscent of other historical narratives, for example, of heroes (teachers) and villains (Alva Myrdal), who personify structural changes. The historical narrative of education also fits in with contemporary trends of modernism criticism.
\end{abstract}

Keywords • Swedish school commission [Skolkommissionen], modernism, use of history [historiebruk], nation

\section{"Där försvann nationalismen - lägg årtalet 1946 på minnet!"}

I Sverige hade länge en diskussion förts om hur skolan skulle reformeras för att bättra passa in i det moderna samhällets krav, en diskussion som intensifierades efter andra världskrigets slut. ${ }^{1} 1946$ tillsattes en statlig offentlig utredning och 1948 presenterade "1946 års skolkommissions betänkande" sitt förslag på hur framtidens skola skulle organiseras. ${ }^{2}$ I korthet innebar förslaget att det rådande parallellskolesystemet avskaffades. Därmed skulle uppdelningen mellan folkskola för arbetare och bönder och läroverk för medel- och överklassen gå i graven. ${ }^{3}$ Systemet med två skolformer ersattes med en gemensam enhetlig och obligatorisk grundskola där alla elever oavsett bakgrund läste enligt samma läroplan. I utredningen föreslogs också en demokratisering av själva undervisningens innehåll och genomförande. En progressivt inriktad metodik med elevens intressen i förgrunden förespråkades. Förslaget

1 För exempel på hur erfarenheterna från andra världskriget påverkade diskussionen om skolans utformning i andra länder som Belgien, Japan, USA och Tyskland se t ex; Marc Depaepe et al, Order in Progress: Everyday Education in Primary Schools - Belgium 1880-1970 (Leuven: Leuven University Press, 2000); Hermann Röhrs och Volker Lenhart, red. Progressive Education Across the Continents (Wien: Peter Lang, 1995); Yoko Yamasaki. "Introduction: Progressivism, New Education, and cultural encounter," i Educational progressivism, Cultural Encounters and Reform in Japan (London: Routledge, 2018); Arthur Zilversmith, Changing Schools: Progressive Education, Theory and Practice 1930-1960 (Chicago: The University of Chicago Press, 1993); Johan Östling, Nazismens sensmoral: Svenska erfarenheter $i$ andra världskrigets efterdyning (Stockholm: Atlantis, 2008).

2 SOU 1948:27, 1946 års skolkommissions betänkande (Stockholm: Häggströms).

3 Den korta beskrivningen av vilka som gick i de olika skolformerna är en viss förenkling.

Johan Samuelsson is Associate Professor of History at Karlstad University, Sweden.

Email: johan.samuelsson@kau.se 
kom i mångt och mycket att lägga grunden för den svenska moderna enhetliga grundskolan, även om delar av förslagen redan var etablerad praxis bland undervisande lärare.

Kommissionens förslag har blivit en central del av svensk skolhistoria, men den har också blivit en återkommande närmast mytisk referenspunkt när skola och samhälle diskuteras. Jämte införandet av en obligatorisk folkskola 1842 är det troligen den mest symboliskt laddade reformen i svensk skolhistoria. ${ }^{4}$ Det inledande citatet är från den kända svenska högerpopulistiska bloggaren Julia Caesar som kommenterar kommissionens betydelse för dagens svenska samhälle. Tolkningen av kommissionen har dock naturligtvis varierat. Tillskyndare av den kallar till exempel kommissionen för den svenska skolans "Magna Charta". ${ }^{5}$ Kommissionen och dess förslag blir här då en central del av demokratiseringen och moderniseringen av det svenska efterkrigssamhället. Skolkommissionen innebar att gamla förlegade ståndstraditioner och den medeltida pedagogiken rensades ut, enligt dessa narrativ. ${ }^{6}$ Kritiker däremot skriver om kommissionen under rubriker som "Solen går ner". ' Skolkommissionens förslag ses av kritikerna som ett destruktivt brott med undervisningstraditioner värda att bevara och som ett farligt modernistiskt experiment.

De senaste åren har historieintresserade skoldebattörer utanför det utbildningshistoriska akademiska fältet skrivit om Skolkommissionen, det är denna icke-disciplinära utbildningshistoria som avhandlas i artikeln.

Den icke-disciplinära historieskrivningen om kommissionen har ofta karaktär av det som historieteoretikern Jörn Rüsen kallar en "kritisk berättelse". Kritiska berättelser används för att legitimera förändringar av olika slag genom att i berättelsen empiriskt och moraliskt peka på brister i det förflutna. Betydelsefulla historiska händelser (som förändringar av skolsystem), personer och epoker är naturligtvis ofta föremål för debatter och inte minst omtolkningar med moraliska fördömanden. Christopher Columbus, finska inbördeskriget och Frankrike under Vichyregimen är internationella exempel där historien på olika sätt omtolkats och "ställts inför rätta". Även en rad exempel från svensk historia har diskuterats och analyserats. Folkhemmet, steriliseringar, skotten i Ådalen och Sveriges agerande under andra världskriget är några historiska fenomen som varit föremål för intensiva diskussioner med tillhörande moraliska anklagelser som lånat begrepp från juridikens begreppsvärld implicit och explicit. Kritiska historiska berättelser av detta slag har ofta just andra upphovsmän än disciplinära historiker, som exempelvis intellektuella, debattörer och politiska organisationer. ${ }^{9}$

Flera av de ovan nämnda historiska exemplen har lett fram till regelrätta politiska eller juridiska sanningskommissioner där staters ageranden i efterhand har renderat

4 Esbjörn Larsson, "On the Use and Abuse of History of Education: Different uses of educational history in Sweden," i Knowledge, Politics and the History of Education. (Münster: LIT verlag, 2012).

5 Åke Isling, Grundskolan för allmänmänsklig kompetens (Stockholm: Sober Förlags AB, 1984), 130.

6 SOU 1948:27.

7 Gunnar Ohrlander, Kunskap i skolan (Stockholm: P.A Nordstedts \& Söners Förlag, 1981), 108.

8 Martin Wiklund, Historia som domstol (Nora: Nya Doxa AB, 2012).

9 Larsson (2012); Roger Johansson, Kampen om historien (Lund: Hjalmarson \& Högberg, 2001); Ulf Zander, Fornstora dagar moderna tider (Lund: Nordic Academic Press, 2001); Yvonne Hirdman, Att lägga livet till rätta (Stockholm: Carlsson, 2010); Maria Pia Boëthius, På heder och samvete (Stockholm: Ordfront, 1999). 
olika målsäganden skadestånd eller ursäkter, exempelvis som i fallet med tvångssteriliseringarna. Men ofta handlar det mer om olika slags ideologiska strider där tolkningen av historiska förlopp tas som intäkt för skuldbeläggande av exempelvis enskilda personer, organisationer, samhällssystem eller ideologier samtidigt som tidigare glömda eller misskrediterade aspekter av historien lyfts fram.

De historiska narrativen har här en viktig roll och de kan sägas fylla funktionen att rättfärdiga samhälleliga förändringar. Narrativet "argumenterar" och bär på en slags sensmoral som fungerar som riktningsgivare för framtiden. En viktig aspekt är att framtidsorientering tar sin utgångspunkt i erfarenheter av samtid och dåtid. ${ }^{10}$

Reformatorer har alltid (?) via dystra historiska narrativ värderat aspekter av skolan negativt, för att motivera reformer. Ett exempel är Skolkommissionens egen historieskrivning där en negativ och förenklad bild målas upp om den äldre undervisningens organisering, innehåll och funktion. Den historiska exposén inleds först med ett konstaterande att framtidens skola måste vila på demokratins grund, men att dagens (1940-talets) skola har "ett starkt medeltida inslag". I historieskrivningen liknades till och med lärare som har "katederundervisning" vid "diktatorer".

Men Skolkommissionen och dess ideologer kom också så småningom själva att bli föremål för historiska "rättegångar" och i vår samtid har flera tongivande debattörer ställt kommissionen och dess ledande medlemmar mer eller mindre inför rätta. Exempelvis konstaterade den välkända svenska författaren, professorn i spanska och skoldebattören Inger Enkvist att Skolkommissionen var en del av en "kulturrevolution" $^{12}$ som raserade en fungerande traditionell skola. Enligt debattörer som Enkvist kan dagens kris i svenska skolan kopplas till Skolkommissionens förslag.

Skolkommissionen är ett välstuderat objekt (se nedan i forskningsgenomgången) men genom att använda aktuella historiografiska teoribildningar och perspektiv där språkliga, kulturella och symboliska fenomen är i fokus kan kunskapen om Skolkommissionen symboliska verkan i samtiden vidgas. De studerade exemplen i artikeln blir också en del av den forskning som intresserar sig för hur historia produceras och används inom en rad områden utanför det akademiska fältet, en forskning som vilar på antagandet att det är närmast en mänsklig reflex att ställa frågor till det förflutna för att kunna förstå sin samtid och peka ut framtidvisioner. ${ }^{13}$

Artikelns övergripande problemområde rör frågan om på vad sätt olika narrativ om skolans historia formuleras, används och blir en resurs i diskussionen om hur skolan och samhället framgent ska utvecklas.

10 Jörn Rüsen, Berättande och förnuft (Göteborg: Daidalos, 2004); Hayden White, Metahistory: The Historical Imagination in Nineteenth Century Europe (Baltimore: Johns Hopkins University Press, 1975); Wiklund (2012). Jämför också med Kosellecks resonemang om "förväntningshorisont " i Reinhart Koselleck, Erfarenhet, tid och historia (Uddevalla: Daidalos, 2004).

11 Se den otryckta inledande historieskrivningen i mappen "Handlingar rörarande Skolkommissionens tillkomst." FIII V1, Skolkommissionen 1946 - 1952 (SK), Riksarkivet (RA). Ingen författare anges till dokumentet, men med stor sannolikhet var det Stellan Arvidson. Se också SOU 1948:27:2; Stellan Arvidson, Skolkommissionen (Lund: Gleerups, 1948); Stellan Arvidson, Skolan vi skall få (Lund: Gleerups, 1950).

12 Inger Enkvist, De svenska skolreformerna 1962-1985 och personerna bakom dem (Möklinta: Gidlunds, 2016), 7.

13 Rüsen (2004), 119-31. Koselleck (2004), 165-75, resonerar på ett snarlikt sätt som Rüsen gällande den nära koppling mellan erfarenhet och förväntan. Han pekar också på "frågeställandets" roll i den historiska praktiken. 
Mer specifikt är artikelns syfte att analysera karaktären på framförallt kritiska och icke-disciplinära historiska narrativ om Skolkommissionen.

Artikeln inleds med en genomgång av studiens teoretiska sammanhang och analytiska utgångspunkter, samt en kortare forskningsöversikt. Sedan följer en presentation av källor och metod. I själva resultatkapitlet ska i huvudsak de moderna narrativen om kommissionen analyseras. Avslutningsvis diskuteras resultaten i relation till studiens problemingång och teoretiska antaganden.

\section{Teoretisk kontext}

Det ökade intresset för narrativ, symboler, minnesmonument, jubileer och andra historiekulturella fenomen har inneburit att det går att tala om "Culture Turn" eller t.o.m en "Narrative Turn" inom historieveteskaplig forskning internationellt sett. Forskningen riktas här mer mot mening, tolkning, och förståelse än av strikta kausala orsaksanalyser. ${ }^{14}$

Historiker som Peter Burke och Eric Hobsbawm har exempelvis visat hur monument, nationellt historieberättande och traditioner länge har varit en viktig resurs i olika ledares maktstrategier. ${ }^{15}$ Genom att exempelvis peka på nationens ursprung och dess nära koppling till specifika dynastier har monarkier befäst sin makt. Kim Salomon, Jörn Rüsen, Hayden White och Stefan Berger har också ur ett mer teoretiskt perspektiv närmat sig betydelsen av narrativens roll inom historiekulturen $i$ allmänhet med också inom historievetenskapen specifikt. ${ }^{16}$

Med en "historisk narration" avses här en form av narration där dåtid, samtid och framtid knyts samman i en sammanhängande historia. Narrationen fungerar ofta identitetsskapande då den binder samman individen med en större helhet, som till exempel en stad, en social rörelse eller för den delen en nation. Men i narrationen ingår också aktörer och en "grundhandling" där tid, plats och aktörer knyts samman till en meningsfull helhet, i dessa narrationer finns vanligtvis en slags sensmoral som på olika sätt förpliktar till agerande. Ofta är detta agerande kopplat till nationsformering eller politisk frigörelse. ${ }^{17}$

Denna artikel kan alltså placeras i en övergripande forskningskontext som kan sägas vara en del av "Culture Turn" eller "Narrative Turn" då intresset riktas mot den betydelse olika historiska symboler och minnen får i samtida debatter om hur samhällen bör organiseras och utvecklas. ${ }^{18}$

14 Georg Iggers, Historiography in the Twentieth Century: From Scientific Objectivity to the Postmodern Challenge (Middletown, CT: Wesleyan, 2005), 118-30. Geoffrey Cubitt, "History of Memory," i Debating New Approaches to History, red. Marek Tamm och Peter Burke (New York: Bloomsbury, 2019), 127-42. Klas Göran Karlsson, "Historia, historiedidaktik och historiekultur: Teori och perspektiv," i Historien är närvarande: Historiedidaktik som teori och tillämpning, red. Klas Göran Karlsson och Ulf Zander (Lund: Studentlitteratur, 2014), 13-89.

15 Peter Burke, "History of Events and the revival of Narrative," i New Perspective on Historical Writing, red. Peter Burke (Cambridge: Wiley, 1993); Peter Burke, Vad är kulturhistoria? (Eslöv: Symposium, 2007); Eric Hobsbawm, Massproducerade traditioner (Lund: Arkiv förlag, 2002).

16 Kim Salomon, "Den kulturella vändningens provokationer," Scandia 75, no 1 (2009); Rüsen (2004); Stefan Berger och Christoph Conrad, The Past as History (Basingstoke: Palgrave, 2015); White (1975).

17 Mario Carretero, Constructing Patriotism. (Charlotte: IAP, 2011); Berger och Conrad (2015).

18 Hobsbawm (2002); Burke (1993, 2009); Salomon (2009). 
En mer avgränsad och central teoretisk och analytisk utgångspunkt tas i Jörn Rüsens resonemang om historiska narrativ och mening (perspektivet kan dock ses som en del av Culture Turn eller Narrative Turn). Tanken är att historiska narrativ genom referenser till vad som upplevs vara reella historiska tidsförlopp rättfärdigar normativt inriktade visioner om framtida förändringar. Dessa narrativ tar sin utgångspunkt i berättarens eller författarens samtida erfarenheter och önskan om förändring. Man kan säga att det sker både en empirisk och en normativ tolkning av det förflutna som bygger på individens samtidsförståelse. Rüsen ser att detta utmärker allt historiskt berättande. En central aspekt av det historiska berättandet är upplevelsen av ett samtida problem och att man i samband med denna upplevelse ställer en "historisk fråga": Hur kunde det bli så här? En slags historisk "fascination" inför det förflutna infinner sig som gör att ett sökande efter historiska spår som kan förklara samtiden påbörjas. Det uppstår i samband med erfarandet av historien alltså en önskan av att tolka och förstå det förflutna, samt ett behov av att förklara varför det ser ut som det gör idag. Förklaringar ges ofta den historiska berättelsens framställningsform och i den ingår, enligt Rüsen, också en orientering mot framtiden. ${ }^{19}$

Rüsen talar om olika slags berättelser men av särskilt intresse i artikeln är vad han kallar en "kritisk berättelse". Den kritiska berättelsen ifrågasätter rådande normer och tolkningar av det förflutna. I denna berättelse vill man ta fram ny kunskap om det förflutna och därigenom kritisera samtiden. Den kritiska berättelsen har klara paralleller till Nietzsches resonemang om kritiskt historiebruk. ${ }^{20}$

Tidigare studier av skolhistoria och historieförmedling har använt andra analytiska begrepp, som till exempel "monumentalistisk" och "antikvarisk" historieskrivning. I den monumentalistiska historieskrivningen används den storslagna historien som förebild när framtida förändringar föreslås. I den antikvariska historieskrivningen finns snarare en fascination av det förflutna och gamla traditioner, dessa narrativ är inte förändringsorienterade. Snarare är det bevarande som fokuseras i antikvariska narrativ. ${ }^{21}$ Om tillskyndare av Skolkommissionen och dess idéer också hade studerats hade fler analytiska begrepp varit relevanta att använda, men frågeställning och empiri har inte varit av den karaktären att det hade varit fruktbart.

I artikeln söker jag efter hur kritiska skoldebattörer använder historiska narrativ för att peka på hur brister i samtidens skola och samhälle ska förstås i relation till historiska misstag gällande skolreformer. Jag förstår detta sökande som ett led i ett genuint historiskt intresse som har uppstått i samband med "ett frågande", ett frågande som vill ha ett svar på vad som kan förklara skolans (och samhällets) kris, samt ett intresse att orientera sig mot framtiden för att förbättra skolan och samhället. Denna ingång innebär inte att jag värderar sanningshalten i de kritiska debattörernas resonemang om det förflutna, mitt intresse riktar sig mot hur det förflutna blir en resurs för att motivera samhälleliga förändringar. Avsikten är inte heller att värdera debattörernas framtidsvisioner.

19 Rüsen (2004), 119-40. Wiklund (2012); se också Koselleck (2004), 165-75.

20 Friedrich Nietzsche, Om historiens nytta och skada (Stockholm: Norstedts, 1998).

21 Nietzsche (1998); Rüsen (2004); Larsson (2012). 


\section{Tidigare forskning}

Det finns forskning som mer eller mindre tangerar artikelns frågeställning om skolans historia som resurs i diskussionen om samhällets och skolans framtida utveckling. Kopplingen mellan nationens överlevnad och kritiken mot en progressiv skola är ett återkommande tema i flera studier. Evans visar exempelvis på föreställningar om hur progressiva utbildningar har förstört dagens (amerikanska) skola. Inte minst har här också tanken om ett "pedagogiskt etablissemang" som en historisk "skurk" varit central. ${ }^{22}$ Symcox pekar också på hur föreställningar om den progressiva skolan har hotat Amerikas kulturarv och ekonomiska framtid genom ifrågasättandet av traditionella värden. Hon hävdar att det en längre tid pågått ett "Culture Wars" kring innehållet i läroplaner och organiseringen av skolan. Vanligtvis har kritikerna av en upplevd progressiv utbildning framhävt betydelsen av en nationell kanon och en mer traditionell kunskapssyn. Symcox pekar också på hur kritikerna mot den progressiva skolan återkommande kritiserat jämlikhetsidealen som format skolan och lyft fram behovet av excellens, hon talar om en "excellent movement" med kopplingar till neo-konservativa grupper. ${ }^{23}$

Den holländske utbildningssociologen Biesta ser också en koppling mellan kritiken mot progressiv utbildning och "Culture Wars", men ur ett europeiskt perspektiv. ${ }^{24}$ Snarlika tendenser lyfter även Malmström fram i sin studie om föreställningar om s.k. skrivkriser i Sverige. Progressiv pedagogik och enhetsskolan har i många sammanhang givits skulden för elevers upplevda skrivproblem. ${ }^{25}$

Men skola och undervisning kan också kodas positivt. Larsson analyserar med hjälp av Nietzsches historiebrukskategorier hur olika aspekter av svensk utbildningshistoria lyfts fram i olika sammanhang. Enligt Larsson tycks ofta skolan (folkskolan) bli en del av en nationell framgångshistoria. Hans huvudsakliga case är folkskolans införande. ${ }^{26}$

Forskning om Skolkommissionen och de reformer och utredningar som påbörjades efter 1946 är relativt omfattade, vilket är naturligt med tanke på dess "gränsbildande" karaktär. ${ }^{27}$ Det finns studier som behandlar efterkrigstidens skolhistoria som delvis berör denna artikels tema, kommissionens och dess starka symboliska roll i svensk skolhistoria. Waldow noterar (utan att närmare studera fenomenet) att Skolkommissionens roll ofta framhävs i närmast devota ordalag av framförallt de utbildningshistoriker och pedagoger som i grunden var positiva till införandet av enhetsskolan. ${ }^{28}$ Övrig forskning har berört frågor som exempelvis debatten om kommissionen, differentieringsfrågan, bakgrunden till reformeringen av skolan, samt

22 Ronald Evans, The Hope for American School Reform (New York: Palgrave Macmillian, 2012); Ronald Evans, The Social Studies Wars: What Should We Teach the Children? (New York: Teachers College Press, 2004).

23 Linda Symcox, Whose History? (New York: Teacher College Press, 2002), 117.

24 Gert Biesta, "Pragmatising the Curriculum: Bringing Knowledge Back Into the Curriculum Conversation, but via Pragmatism," Curriculum Journal 25, no. 1 (2014), 29-49.

25 Martin Malmström, Synen på skrivande: Föreställningar om skrivande i mediadebatter och gymnasieskolans läroplaner (Lund: Studies in Educational Science Lund University, 2017).

26 Larsson (2012).

27 Per Johan Ödman Kontrasternas spel, Del 2 (Stockholm: Norstedts, 1995), 596.

28 Florian Waldow, Utbildningspolitik, ekonomi och internationella utbildningstrender i Sverige 19302000 (Stockholm: Stockholms universitets förlag, 2013). 
pedagogikämnets framväxt. ${ }^{29}$ Dock ligger den forskningen utanför denna artikels mer avgränsade syfte och kommer därför inte redogöras för närmare.

\section{Metod, analys och urval}

Historiska narrativ ges i detta sammanhang en bred betydelse och handlar om redogörelser som knyter samman då med nu via någon form av intrig. Intrigen är avgränsad till tid och rum och har vanligtvis några aktörer som driver handlingen framåt. I analysen lästes i ett första skede texterna noggrant för att få syn på själva grundintrigen i texterna som behandlar skolans problem. De studerade texterna handlar i samtliga fall om skolans och delvis även det svenska samhällets förfall generellt och jag har då sökt efter just kommissionens skuld till detta förfall.

Med stöd i denna närläsning har sedan en fördjupad analys av narrativets "sensmoral" gjorts. För att fånga sensmoralen i narrativet har jag försökt identifiera centrala aktörer (vanligtvis personer) som ges en central betydelse för händelseutvecklingen, samt i förekommande fall sett på vilka karaktärsdrag de ges (hjälte eller skurk till exempel). För att komma åt textens budskap har jag även sökt efter värderande begrepp och perspektiv, som till exempel beskrivningen av Myrdals bristande föräldraskap (Enkvist om Myrdal) eller "Solen går ner" (Ohrlanders rubrik där kommissionen behandlas för första gången i en av hans böcker).

Jag har också strävat efter att se på vad som upplevs vara problemet med dagens skola och på vad sätt detta beror på Skolkommissionen. Slutligen har författarnas olika perspektiv på hur de vill förändra skolan och eventuellt samhället analyserats. Genom dessa delar i analysen kommer jag delvis åt aspekter av frågande, erfarande, tolkning och framtidsorientering som Rüsen ser som centrala komponenter i sin teori.

De olika analysstegen har varit överlappande och flera omläsningar av hela texten har gjorts. Det övergripande tillvägagångssättet kan sägas ha inspirerats av s.k. idéanalys. ${ }^{30}$

Jag har valt att göra en form av case-studie där enskilda exempel får utgöra de empiriska exemplen som analyserats. Ambitionen är inte att analysera hela den samtida debatten om skola och samhälle, utan syftet är att se på hur historiska narrativ om Skolkommissionen kan användas i debatten av debattörer som radikalt vill förändra skolan. Några principer fanns vid urval av case. De författare som studeras ska vara namnkunniga och deras böcker eller texter om skolans historia ska vara utgivna på etablerade förlag eller kända plattformar. Ambitionen i val av material har också varit att hitta texter vars upphovsmän använder sig av "publiceringskanaler" av varierande karaktär, samt att författarna har olika övergripande ideologisk hemsvist.

29 Sofia Persson, Läraryrkets uppkomst och förändring (Göteborg: Göteborg Studies in Sociology, 2008); Johan Samuelsson, "Âmnesprofessionalitet under omförhandling: Exemplet historielärarna kring 1940-1965," Didaktikens forum 3 (2008); Johan Samuelsson och Christin Olin-Scheller, Teachers in the Borderland of Elementary School, Grammar School and Comprehensive School: Teachers on Teaching in the 1940s, NOFA 6 (Nordic conference on school subjects, University of Southern Denmark, Odense, 29th - 31st of May 2017); Bo Lindesjö och Ulf P. Lundgren, Utbildningsreformer och politisk styrning (Stockholm: HLS Förslag, 2006); Christian Lundahl, Viljan att veta vad andra vet (Stockholm: Arbetslivsinstitutet, 2006); Ulf P. Lundgren, Att organisera omvärlden (Stockholm: Utbildningsförlaget, 1989); Gunnar Richardson, Svensk skolpolitik 1940-1945 (Stockholm: Liber, 1978); Gunnar Richardson, Drömmen om en ny skola (Stockholm: Liber, 1983).

30 Peter Esaiasson, mfl., Metodpraktikan: Konsten att studera samhälle, individ och marknad (Stockholm: Norstedts juridik, 2007). 
Statistisk information om upplagornas storlek eller annan information om texternas spridning har inte varit tillgänglig. Jag har utgått från respektive persons ställning i det offentliga samtida samtalet om skolan inom respektive sammanhang. Det går att alltså att se dessa texter, enligt mig, som en form av "nyckeltexter" i den kritiska diskussionen om svenska skolan. Notera att jag av avgränsningsskäl bara valt författare som varit aktiva på 2000-talet. När det gäller en av författarna, Gunnar Ohrlander, har två böcker av honom analyserats. Den sista kom ut 2009, men den första 1981. Jag har valt att inkludera boken från 1981 då flera av grundantagande i boken från 2009 bygger vidare på den första boken.

De analyserade texterna kan beskrivas som debattinlägg om skolan, inte rent vetenskapliga studier inom området utbildningshistoria. Dock kan Inger Enkvists bok ses som en slags hybridtext. Enkvist är professor i spanska, men inte skolad utbildningshistoriker. En studie av Skolkommissionens roll i traditionella historiografiska studier hade varit relevant. Men då artikeln är intresserad av hur skolhistoria förstås, produceras och används i ett bredare samhälleligt sammanhang har akademisk historieskrivning inte inkluderas. Urvalet kan med stöd i ovan förda resonemang ses som ett strategiskt och syftesrelaterat. ${ }^{31}$

Med hjälp av materialurvalet går det, enligt mig, att resonera och kvalificera diskussionen om hur skolhistoria kan användas i offentlig debatt om skola och framtid. Jag har däremot inte haft som ambition att generalisera i statistisk mening om hur frekvent denna sorts användande av skolhistoria är, snarare är det en form av "teoretisk generalisering" som ska göras Det innebär att casen eller fallen diskuteras och förstås i relation till teoretiska perspektiv. ${ }^{32}$

Böcker av två författare, Inger Enkvist och Gunnar Ohrlander, har analyserats närmare. Båda författarna har (Ohrlander är numera avliden) en längre tid varit aktiva skribenter och författare som kritiserat tillståndet i den svenska skolan, dock med olika ideologiska utgångspunkter. Ohrlander bör klassificeras som "vänster", medan Enkvist kan ses som "borgerlig". Inte minst märks det på de plattformar de valt att torgföra sig på. Ohrlander skrev fram till sin död på för den socialdemokratiska Aftonbladet, Enkvist skriver krönikor i bland annat konservativa Svenska Dagbladet.

Även en text av annan karaktär har inkluderats, en bloggtext från en väletablerad skribent inom högeralternativa media, "Julia Caesar". Julia Caesar är en pseudonym och hon har tidigare varit DN-skribent. Nu skriver hon på kända högerportaler som danska högerpopulistiska Snapphanen. ${ }^{33}$ I resultatredovisningen beskrivs författarna närmare. I den presentationen diskuteras också varför författarna är lämpliga att ha som case när en mer samtida förståelse av Skolkommissionens roll önskas.

Genom valet av tre författare som använder/använde tre olika samhällspolitiska arenor (socialdemokratiska Aftonbladet, konservativa Svenska Dagbladet och högerpopulistiska plattformar) ges också möjlighet att i vart fall i princip ha en komparativ

31 Alan Bryman, Social Research Methods (Oxford: Oxford University Press, 2012).

32 Robert Yin, Case Study Research: Design and Methods (London: Sage, 2014).

33 Selänkar till krönikor på: “Svenska skolans sjunkande elevresultat" http://snaphanen.dk/2012/11/06/ svenska-skolans-sjunkande-elevresultat/. 
ansats så tillvida att det finns likheter genom kritiken av Skolkommissionen, men också skillnader då författarna har olika ideologiska perspektiv.

\section{Från fel kunskapssyn till moralupplösning, resultatredovisning}

Som redan påpekats har Skolkommissionen och inte minst personerna som hade ledande positioner i arbetet en central roll i svensk efterkrigshistoria. Tage Erlander som initialt var kommissionens ordförande blev sedermera partiledare för Socialdemokraterna och också statsminister 1946-1969. Alva Myrdal som var en av centralfigurerna i arbetet är en av de mest kända svenska politikerna och samhällsreformatörerna. Hon fick Nobels fredspris, var minister och skrev tillsammans med sin make Gunnar Myrdal fler klassiska svenska böcker om välfärdsfrågor. Huvudsekreteraren Stellan Arvidson kallas i många sammanhang "enhetsskolans fader" och han kom också att inneha en central position i andra skolutredningar. Arvidson kom vidare i rollen som ordförande för vänskapsförbundet Sverige-DDR bli en mycket omstridd och kritiserad person. Arvidson som person har också blivit föremål för biografisk forskning. ${ }^{34}$

Att kommissionen alltjämt utgör en referenspunkt i dagens samhällspolitiska diskussion om skola och samhälle beror inte främst på dess namnkunniga medarbetare, även om det säkerligen spelar en inte obetydlig roll. Kommissionens roll i dag beror i hög grad på att den i mångt och mycket, vilket beskrevs inledningsvis, kom att staka ut den principiella vägen mot en enhetlig skola med en i huvudsak progressiv pedagogik. Även om stora förändringar har skett inom det svenska skolväsendet, ligger många av grundtankarna fast från kommissionens förslag 1948.

Kommissionen har också i mer samtida skolutredningar utgjort en referenspunkt och dess kunskapssyn och perspektiv på lärarrollen har kritiserats. ${ }^{35}$

\section{"Solen går ner"}

Åtminstone sedan tidig 1970 har kommissionen och enhetskolan varit föremål för kritik, en kritik som ofta kombinerats med en krisretorik om en skola i förfall. Dessa föreställningar kan kopplas till vad Malmström kallar för "myten om progressivismen" som orsaken till skolkrisen. Kommissionen och inte minst de som ansvarade för arbetet med den får då personifiera såväl kommission som skolans förfall. ${ }^{36}$

Gunnar Ohrlander var fram till sin död nyligen en framträdande debattör som hade Sveriges största tidning Aftonbladet som plattform. Ohrlander kan karaktäriseras som "vänster", men han var en redan på 1970-talet ute och kritiserade den svenska skolans kunskapsförfall och han var också en del av det som i Sverige kallades "kunskapsrörelsen", en rörelse som ville återupprätta den traditionella kunskapens plats i skolan. Ohrlander, var trots sin vänsterprägel, en författare som refererades i många olika sammanhang som till exempel i den konservativa Svenska Dagbladet. ${ }^{37}$ Hans texter om bland annat Skolkommissionen har också ofta använts när forskare och debattörer förespråkat en mer "kunskapsinriktad" skola med fokus på "ordning

34 Birgitta Almgren, Dröm och verklighet (Stockholm: Carlsson, 2016).

35 SOU 1974:53, Skolans arbetsmiljö (Stockholm: Allmänna förlaget), 891. SOU 1992:94, Skola för bildning (Stockholm: Nordstedts), 61.

36 Malmström (2017).

37 Maria Ludvigsson, "Det var ni som svek arbetarbarnen," Svenska Dagbladet, 25 januari, 2018. 
och reda". ${ }^{38}$ Ohrlander är ofta citerad i "krislitteratur" om skolan där författarna förespråkar en mer lärarcentrerad skola. ${ }^{39}$ Ohrlander drevs länge av ett vad som måste ses som genuint intresse att förbättra den svenska skolan.

Redan 1981 kom "Kunskap i skolan". Boken tar tydlig avstamp i en upplevelse av att det är något fundamentalt fel med dagens skola och Ohrlander ställer redan i inledningen en fråga: "Varifrån kommer våra traditioner, de goda och dåliga? Hur kunde så många ryckas med av idéer som inte höll för verklighetens påfrestningar?"40 Historiska tillbakablickar måste göras för att få svar på frågan enligt författaren.

Samtidens skola relateras också till en generell nationell historia perioden $1842-$ 1980, även om skolan och efterkrigstiden är i fokus. Starten tas i en slags programförklaring "Jag tyckte skolan var ganska bra" ${ }^{41}$ och syftar på författarens egen skolgång $\mathrm{i}$ folkskola och realskola. Inledningskapitlets första underrubrik är "Guldåldern" ${ }^{42}$ och syftar just på den tidsperiod författaren själv gick i skola (1940-1950-talet). Kunskapen stod fokus och "man kunde bli något" genom studier, även om det fanns ett destruktivt klassamhälle bejakades strävsamhet och framtiden såg ljus ut. Lite längre fram i boken återkommer han efter en utbildningshistorisk fördjupning till första hälften av 1900-talet. Det fanns i samhället, enligt Ohrlander, en "förståelse för traditionen och ett folkligt, kulturellt normsystem som det var värt att slå vakt om". Men det "kulturradikala upproret" 43 vände sig mot detta system via bland annat Alva Myrdal. Lite senare i boken konstateras att "Kulturradikalismens inväxande i den offentliga förvaltningen skulle emellertid varken resultera i kultur eller radikalism".44 Snarare ledde den till en destruktivt maktutövande offentlig sektor och Ohrlander kallar denna tendens för "nyfeodal". ${ }^{45}$ Ohrlanders beskrivning av "guldåldern" kan förövrigt jämföras med Skolkommissionens egen beskrivning av skolan på den tiden som "medeltida". ${ }^{46}$

Skolkommission behandlas mer omfattande med start i kapitlet "Solen går ner". Där konstateras att Skolöverstyrelsen (SÖ) föreslog att skolans viktigaste uppgift inte var kunskapsförmedling, utan fostran och allsidig utveckling. SÖ skulle nu 1978 förverkliga dessa idéer med långa historiska rötter. SÖs förslag måste således förstås i relation till den utredning som förändrade den svenska skolan i grunden, Skolkommissionen. "Det är inom denna som många av trådarna binds samman och det är skolkommissionens idéer som 1978 års SÖ-förslag följde upp och sökte realisera" konstaterar Ohrlander. ${ }^{47}$ Ohrlander fortsätter sedan att teckna en bred bild av det historiska sammanhanget där "fri uppfostran" i "ultraliberal" anda var

\footnotetext{
38 Jonas Frykman, "Skolan måste lära barnen vanligt hyfs," Expressen, 20 december, 2013.

39 Jonas Frykman, Ljusnade framtid (Lund: Historiska media, 2014); Enkvist (2016).

40 Ohrlander (1981), 13.

41 Ohrlander (1981), 11.

42 Ohrlander (1981), 14.

43 Ohrlander (1981), 114.

44 Ohrlander (1981), 117.

45 Ohrlander (1981), 118.

46 SOU 1948:27, 2.

47 Ohrlander (1981), 110.
} 
ledande idéer. ${ }^{48}$ Bondesamhällets "sociala trafikregler, som utformats under tusentals år" ${ }^{\prime 49} \mathrm{kom}$ nu att via tankarna om fri uppfostran ifrågasättas.

Enligt Ohrlander var Alva Myrdal drivande i arbetet och hon propagerade för det fria skapandet och läxläsningens borttagande. "Det kulturradikala angreppet på gamla ideal" ledde i förlängningen till "knark-, vård- och superliberalism med hyllandet av ohämmad driftsupplevelse och ett stigande förakt för arbetets värde och därmed också för arbetarklassen" skriver Ohrlander. ${ }^{50}$

Dock var inte allt Skolkommissionens fel: "På sätt och vis var det högerledaren Gösta Bagge som började"51 då hans skolutredning betonade fostran före kunskap. Detta gjorde Skolkommissionen till ledstjärna. Den "planlagda kunskapsförmedlingen och metodiska inlärningen" ${ }^{22}$ städades således bort. Jämte ifrågasättandet av fast kunskap gjorde kommissionen också "upp med den planlagda moralbildningen". ${ }^{53}$

Det grundläggande narrativet kretsar kring den kulturradikala Alva Myrdals historiska skuld. Hon och kommissionen kom att fånga upp samtida föreställningar om fri uppfostran och elevcentrerad undervisning. Detta i kombination med ett ifrågasättande av skolans kunskapsförmedlande roll fick förödande konsekvenser för skolan. Det innebar ett förakt för "vanligt folk" och samtidigt moralupplösning. Konsekvenserna av detta ser vi nu (1978/81). Sensmoralen i narrativet är alltså att om samhället löser upp traditionella normer och naturliga hierarkier och kombinerar det med förakt för kunskap kommer "vanligt folk" bli lidande genom sämre framtidsmöjligheter.

Framtidens skola bör vara kunskapsfokuserad för att inte den "härskande klass[en]" ${ }^{54}$ ska kunna fortsätta att förtrycka arbetarklassen. Genom att erbjuda alla riktig kunskap kan ett bättre samhälle byggas för alla medborgare i Sverige.

\section{Det pedagogiska etablissemanget och kunskapsskolans förfall}

2009 kom Ohrlanders sista bok, "Den gudarna älskar". Det grundläggande narrativet från "Kunskap i skolan" ligger i huvudsak fast med Skolkommissionen som en central aktör. Dock har narrativet kompletterats med ytterligare aktörer och teman. Ett exempel på ett upplevt samtida problem blev nu till exempel frågan om friskolesystemet och eleven som en kund på skolmarknaden.

Hur ser då det grundläggande narrativet ut i "Den gudarna älskar"? Den traditionella skolan med kunskapsförmedling i centrum kom under 1930-1940-talet allt mer utmanas av aktivitetspedagogik. Skolkommissionens fokus på "fri uppfostran" och "personlighetsdaning" inledde skolans fall. I kommissionen fick "kunskapen" bara "några få spaltcentimeter" och den fria uppfostran var alltjämt problemet enligt Ohrlander. ${ }^{55}$ Dock var även tidigare skolutredare medskyldiga till skolans felaktiga vägval.

\footnotetext{
48 Ohrlander (1981), 112.

49 Ohrlander (1981), 113.

50 Ohrlander (1981), 115.

51 Ohrlander (1981), 119.

52 Ohrlander (1981), 120.

53 Ohrlander (1981), 121.

54 Ohrlander (1981), 250.

55 Ohrlander (2009), 93.
} 
Till narrativet om kunskapskolans fall har nu också pedagogikämnet och det "pedagogiska etablissemanget" 56 tillkommit som en aktör. Pedagogerna hade också via två generaldirektörer fått ett negativt inflytande på skolan då de ytterligare tonade ner kunskapens roll i skolan. ${ }^{57}$ Även lärarutbildningen (specifikt lärarutbildningen i Stockholm) sågs som en bromskloss för en kunskapsinriktad skola och lärarutbildningen beskrevs bland annat som en "pedagogisk ankdamm". ${ }^{8}$

Men folkpartisten Birgit Rodhe och moderaten Britt Mogård beskrevs som medskyldiga i och med SÖs förslag om att fostran och inte kunskap skulle vara huvudfokus för skolan. Mogård och Rodhe var delaktiga i att ytterligare göra skolan till en "flumskola". ${ }^{99}$ Även friskolesystemet och kommunaliseringen blev aspekter av skolhistorien som var skadliga för skolan.

Samtidigt fanns det vissa hjältar i berättelsen, Skolverkets generaldirektör Per Thullberg som hörde hemma i "universitetstraditionen" ${ }^{60}$ och inte den pedagogiska traditionen var till exempel en positiv gestalt. Till skillnad från sina företrädare hade han inga pedagogisk lik i lasten. Det finns också en rad lärare och andra sanningssägare som trots skolans utsatta läge ingav hopp om kunskapsskolans återupprättelse.

Skolkommissionen ställdes alltså alltjämt inför rätta men man kan säga att skulden nu också delades med andra samtida aktörer som det pedagogiska etablissemanget. Sensmoralen i Ohrlanders narrativ är att brott mot traditioner, respekt för auktoriteter, traditionell kunskap och marknadsstyrning leder till en skola som missgynnar arbetarklassens barn. Sammantaget förordades en kunskapsskola där respekt för läraren, traditioner och auktoriteter är centralt. Genom att åter sätta läraren i centrum kan vi i framtiden "hjälpa våra barn att bli kunniga och sociala varelser". ${ }^{61}$

\title{
Kulturrevolutionen
}

"När nu Sverige har sjunkit i PISA-jämförelserna, har det uppkommit en debatt om när problem började. Många debattörer tror att nedgången inleddes med kommunaliseringen och friskolereformen" 62

Citatet är från professorn i spanska Inger Enkvist. Hon är en ledande äldre skoldebattör som har regelbundna krönikor i en av de stora rikstäckande morgontidningarna, Svenska Dagbladet. Krönikorna kretserar ofta kring kunskapsskolans förfall och den krisande skolan i allmänhet. Hon är en av medförfattarna till boken "Kunskapssynen och pedagogiken" där hon tillsammans med medförfattarna driver tesen att den svenska läroplanen numera är postmodern, vilket bidrar till att förklarara skolans förfall. ${ }^{63}$ Hon medverkar också regelbundet i webbtidningen/portalen Det goda samhället som krönikör. Temat för hennes krönikor kretsar även här kring krisen i skolan och bristen på meritokratiskt tänkande i Sverige. Det goda samhället drivs av intressegrupper med koppling till näringslivets tankesmedjor. Liksom hos

\author{
56 Ohrlander (2009), 95. \\ 57 Ohrlander (2009), 108. \\ 58 Ohrlander (2009), 179. \\ 59 Ohrlander (2009), 95. \\ 60 Ohrlander (2009), 110. \\ 61 Ohrlander (2009), baksidestext. \\ 62 Enkvist (2016), 7. \\ 63 Magnus Henrekson, mfl. Kunskapssynen och pedagogiken (Stockholm: Dialogos, 2017).
}


Ohrlander finns det ett genuint intresse hos Enkvist att förbättra den svenska skolan, en fråga hon länge varit engagerade i. Läsaren av boken får också via baksidestexten reda på att författarens egen negativa erfarenhet av skolan och vi meddelas att Enkvist "iakttagit på nära håll hur den systematiska förstörelsen av skolan gått till". ${ }^{64}$ För att använda begrepp från Rüsen, det är uppenbart att Enkvists negativa "erfarande" av skolan också har fått henne att ställa frågor till historien för att utvecklingen har varit katastrofal.

I det inledande citat görs ett uppfodrande påstående om att dagens kunskapsras i skolan inte kan förklaras med kommunalisering och friskolesystemet, Enkvist söker sig betydligt längre tillbaka när fallet ska förklaras. Skolkommission blir här medansvarig till skolans förfall. I boken "De svenska skolreformerna 1962-1985 och personerna bakom dem" berättas en historia som känns igen från exempelvis Ohrlander men samtidigt har, som titeln antyder, personer som aktörer i historien nu fått större roll.

Boken är ett led i ett större privat stiftelsefinansierat projektet om den svenska 68-vänstern. Övriga böcker handlade om fenomen med direkt koppling till 1968, som till exempel boken om "68-kyrkan" av Johan Sundeen. ${ }^{65}$ Enkvist hade uppdraget att skriva om koppling mellan skolans utveckling och 68-vänstern. I boken ges dock ett betydande utrymme åt kommissionen och framförallt Alva Myrdal och Stellan Arvidson. Enkvist uppmärksammar visserligen att de inte var aktiva 1968 (De var födda 1902) men för att förstå bakgrunden till de idéer som fick fotfäste då måste deras gärningar beskrivas. I slutordet sägs att "progressivismen som pedagogisk statsideologi" i hög grad alltjämt påverkar svensk skola. ${ }^{66}$ Progressivismen som idé fanns redan i Myrdals 30-talstänkande och Skolkommissionens pedagogiska credo, vilket motiverar att en studie av 40-talets skolpolitik görs när 1968 ska diskuteras enligt Enkvist.

Grundnarrativet är bekant från tidigare narrativ där Skolkommissionen ges skulden till dagens upplevda skolkris. Ohrlanders (1981; 2009) böcker refereras exempelvis också i boken. Men skillnader finns och framförallt handlar det om vad som är den grundläggande drivkraften i historien och hos Enkvist är det utmärkande draget personifieringen av historien. Progressivismen och Skolkommissionen kan sägas inkarneras i Myrdal och Arvidson (tillsammans med några andra aktörer) som får utförliga personporträtt i boken.

Narrativet är följande. Kommissionens arbete ledde fram till grundskolereformerna som innebar en "kulturrevolution light" ${ }^{67}$ och ett förkastande av lärdomsskolan. Drivande i arbetet var Myrdal och Arvidson. Myrdal ifrågasatte tanken om lydnad och hon ville göra eleverna till självständiga individer via en progressiv skola. Skolan blev för Myrdal ett instrument att omdana samhället. Resultatet av de idéer som lades fram i Skolkommissionen ser vi än idag verkningar av, främst manifesterat i fallande kunskapsresultat och bristande respekt för meritokratiska principer.

Personifieringen av historien är som sagt genomgående påtaglig:

Alva Myrdal, Stellan Arvidson och Britta Stenholm är centrala personer i den utveckling vi ska studera. Den inställning till utbildning som de propagerar för redan

64 Enkvist (2016), baksidestext.

65 Johan Sundeen, 68-kyrkan (Stockholm: Bladh by Bladh, 2017).

66 Enkvist (2016), 244.

67 Enkvist (2016), 7. 
på 1940-talet, i Myrdals fall till och med tidigare, kom att få ett avgörande inflytande på de reformer som kom att införas, reformer som inte baseras på vare sig lärarerfarenhet eller framgångsrika skolförsök. ${ }^{68}$

I boken konstateras också att Myrdal som ledamot av kommissionen kunde använda skolan för att omdana samhället. ${ }^{69} \mathrm{Om}$ Arvidson sägs att han tillsammans med Myrdal var "den viktigaste ideologen bakom tillkomsten av den svenska grundskolan" och att hans inflytande var "intensivt och bestående" ${ }^{70}$ Enkvist hävdar vidare att "det är svårt eller omöjligt att urskilja hans åsikter från de kollektiva åsikter som uttrycks i kommittédokumenten". ${ }^{71}$

Personerna är viktiga aktörer och deras personliga egenskaper lyfts fram i texten. Det konstateras till exempel att Myrdal hade påtagliga brister som mor genom referat från barnens självbiografier, Enkvist skriver att barnen "ofta lämnades åt andra eller drev vind för våg. Ingen kontrollerade att de var hemma vid en viss tid eller att de var hela och rena när de gick till skolan".72

Narrativet innehåller en slags dubbel anklagelseakt mot framförallt Alva Myrdal då hon anklagas båda för att vara en dålig mor och för att ha varit drivande i de skolreformer som ledde fram till kunskapsskolan nedmontering. Men även Stellan Arvidsons agerande i andra sammanhang än i själva kommissionsarbetet lyfts fram, till exempel berättas det om hans engagemang i vänskapsförbundet Sverige-DDR. Just Arvidsons engagemang i förbundet är något som också i andra sammanhang lyfts fram för att visa på kopplingen mellan enhetsskoletanken och DDR. Se här till exempel Per Gudmundson och hans artikel "Svenska skolan skulle förbereda socialismen". Artikel handlar om kopplingen mellan svenska skolan och DDR, ledarartikeln illustreras med en bild på Arvidson framför en DDR-flagga och med bildtexten: "Socialdemokraten Stellan Arvidson var arkitekten bakom den moderna svenska skolan - och ordförande för Förbundet Sverige-DDR" ${ }^{73}$

Den framtidsvision av skolan som framträder i boken handlar om upprättandet av kunskapsskolan (vilket vi känner igen från Ohrlander) men även indirekt en tydligare uppdelning mellan olika studiegångar och en tidigare differentiering, vilket vi inte ser hos Ohrlander. Sensmoralen i narrativet har likheter med Ohrlanders narrativ men här är finns inte samma explicita kritik mot marknadsstyrningen, snarare är poängen att modernismen och välfärdssamhället innebar ett brott mot traditionella värden och meritokratiskt tänkande. Nu ser vi resultatet av detta via fallande resultat i internationella kunskapstest.

68 Enkvist (2016), 12. Dock kan man notera att kommissionens arkiv visar att tidigare forskning, erfarenheter från andra länder och lärares praktik var viktiga. För resonemang om insamling av lärares undervisningspraktik, se "Bilaga D till protokoll nr 14." 27 februari . A1 V2, SK, RA. Se också bilagorna "Bilaga B till protokoll nr 14, Alva Myrdal" 27 februari och "Bilaga C till protokoll nr 14, John Almgren" 27 februari. A1 V2, SK, RA. I dessa bilagor lägger kommissionen upp arbetet med att samla in kunskaper från forskning och andra länders skolsystem.

69 Enkvist (2016), 13.

70 Enkvist (2016), 14.

71 Enkvist (2016), 17.

72 Enkvist (2016), 237. Noteras bör dock att personifiering av kommissionen är ett återkommande drag i merparten av standardverken om svenska utbildningshistoria, se t ex Lindesjö och Lundgren (2006); Lundgren (1989) och Richardson (1983).

73 Per Gudmundson, "Svenska skolan skulle förbereda för socialismen," Svenska Dagbladet, 29 oktober, 2016. 


\section{"Där försvann nationalismen", högerpopulister och Skolkommissionen}

I en artikelserie på sin egen blogg hade den högerpopulistiska bloggaren och skribenten Julia Caesar (en pseudonym) en artikelserie om skolsverige och tanken med texterna var att försöka förstå varför "det spåra[de] ur så till den grad?".

Caesar är en f.d skribent på bland annat Dagens Nyheter. Men hon har också medverkat som krönikör på danska högerpopulistiska Snapphanen ${ }^{74}$ och svenska högerpopulistiska plattformar som Avpixlat delade information om hennes texter. Hon har också ett populärt twitterkonto med drygt 5000 följare och egen blogg. Caesar kan ses som en känd högerpopulist som använder sig av "alternativmedia" för att kritisera den "politiska eliten" och "kulturmarxisterna". Enligt Dagens Nyheter är hon en av de mest inflytelserika inom den svenska "anti-invandringsrörelsen". Hon refereras och kommenteras också av etablerade medier som Expressen. ${ }^{75}$

Texten om skolans utveckling och Skolkommissionen inleds med ett "När någonting går så helgjutet åt skogen som skolan har gjort bör man nysta i rötterna och försöka ta reda på hur och var det började gå snett". ${ }^{76}$ Sedan följer sammanfattningsvis ett narrativ där det konstateras att reformatorerna (främst Stellan Arvidson) ville väl med en demokratisk skola men att hans visioner fick förödande konsekvenser. Ifrågasättandet av kunskap, respekt för auktoriteter och inte minst det nationella kulturarvet lede på sikt fram till en krisande skolan som ska hantera människor med olika bakgrund och intelligens. Kommissionens genomslag förklaras i hög grad via Arvidson som aktör i historien.

Tanken att fostra människor att stå emot antidemokratiska rörelser har misslyckats då Sverige låter Islam ta över allt mer konstateras och avslutningsvis ställs frågan: "Vilken medvetenhet och vilken motståndskraft har skolan att erbjuda mot det största hotet mot våra demokratier och vårt jämlikhetstänkande i dag?"77

I relation till tidigare narrativ finns flera likheter, till exempel framlyftandet av föraktet mot "vanligt folk" hos reformatorerna då deras syn på kultur och smak präglades av "elittänkande och folkförakt". ${ }^{78}$ Likaså kritiken av upplösning av moral och respekt för auktoriteter är aspekter som till exempel även Ohrlander lyfter fram i sin bok från 1981.

Det finns även betydande likheter till andra narrativ gällande själva uppbyggandet av narrativet gällande aktörer. Liksom hos Enkvist berättas historien om kommissionen genom att lyfta fram enskilda aktörer. Aktörernas värderingar och inte minst ideologiska övertygelser blir också centrala hos Caesar, men här läggs större vikt vid Arvidson (Noteras bör att också "älskarinnan" Britta Stenholm ses som en aktör i narrativet).

Men det finns också betydande skillnader mellan de olika narrativen och framförallt är det betoningen av att patriotism och nationalismen försvann som grundelement i svenska skolan på grund av kommissionen som utmärker Caesar i relation till Ohrlander och Enkvist. ${ }^{79}$

\footnotetext{
74 Se t ex information om hennes krönikor på Snaphanens hemsida intill artikeln "Svenska skolans sjunkande elevresultat," http://snaphanen.dk/2012/11/06/svenska-skolans-sjunkande-elevresultat/

75 Niklas Orrenius, "Om mötet med Julia Caesar," Dagens Nyheter, 5 september, 2015.

76 Julia Caesar, "Skoldrömmar som brast del 2" https://juliacaesar.blog/2018/03/05/skoldrommensom-brast-del-2/ Se också "Skoldrömmar som brast del 1"

77 Caesar (2018).

78 Caesar (2018).

79 Det finns heller ingen kritik av det mångkulturella samhället hos Ohrlander och Enkvist.
} 
Det var inte moralisk fostran och patriotism som skulle stå i centrum - där försvann
nationalismen - lägg årtalet 1946 på minnet! Inte heller kristendom som samman-
hållande grund av värderingar - där kom ateisten fram. Auktoritets- och disciplin-
fostran skulle mönstras ut. ${ }^{80}$

Sensmoralen i narrativet är sammanfattningsvis att bristen på respekt för traditionell kunskap och nedmonteringen av västerländska kristna värderingar som följde i Skolkommissionens kölvatten lade grunden för dagens krisande nation där mångkulturalism och islamisering går hand i hand med en krisande skola. Visionen om framtidens skola (och framtidens Sverige) framträder indirekt i dessa texter. Jämte det närmast självklara framlyftandet av en kunskapsskola är också betoning av att kunna tänka kritiskt centralt, men det är i relation till Islam. Skolan ska inte längre vara en institution för indoktrinering i "mångkulturalism". Framtidens skola (min tolkning) bör främja en god samhällsmoral och ett patriotiskt sinnelag. Om skolan förmår detta kan det bidra till ett framtida mer homogent Sverige.

\section{En krisande skola och en risig nation, sammanfattande diskussion}

När människor i sin samtid erfar grundläggande problem med ett fenomen är det vanligt att "ställa frågor" till det förflutna för att kunna tolka samtiden och orientera sig mot framtiden. Ofta kan det ske i form av "kritiska berättelser". Dessa berättelser pekar på brister i det förflutna och kopplar det till samtida problem samtidigt som det finns framtidsorienterande förändringsförslag. I kampen om att formulera lösningar på samtida problem har det förflutna inom många områden således haft en central roll. Historiska narrativ rättfärdiggör olika handlingsinriktningar och bär genom detta på ett slags dömande sensmoral som å ena sidan förhåller sig kritiskt till det förflutna, men å andra sidan pekar ut alternativa framtidsalternativ. ${ }^{81}$ Dessa narrativ har ofta en ideologisk karaktär då orsaksförklaringar, exempel från historien och inkluderade teman är bärare av mening och politiska förklaringsmodeller. Författare till kritiska historiska narrativ har också ofta en icke-disciplinär bakgrund, vilket tidigare forskning ${ }^{82}$ och denna artikel visar.

Skolkommissionen blir en slags resurs som kan användas för att mobilisera ideologiskt kapitel när förändringar av skolan ska motiveras, minnet av skolhistorien kan sägas aktiveras för att brukas politiskt. Tolkningen av det skolhistoriska fenomenet blir viktigt på samma sätt som tolkningar av exempelvis skotten i Ådalen blev för svensk arbetarrörelse ${ }^{83}$ För att inte upprepa misstagen från Skolkommissionen föreslås en ny framtidsvision; en skola som betonar traditionell kunskap och traditionell undervisning och som samtidigt vilar på en respekt för traditionella värderingar och naturliga hierarkier med läraren i fokus för undervisningen. Om denna vision förverkligas kommer fler elever att kunna lyckas och Sverige som nation att resa sig. Denna tolkning av Skolkommissionen skiljer sig från tidigare historiska narrativ som till exempel sett kommissionen som en slags "Magna Charta" för skolan. I dessa narrativ var kommissionen lösningen, inte problemet, på samhällets utmaningar.

80 Caesar (2018).

81 Rüsen (2004); Wiklund (2012).

82 Zander (2001).

83 Johansson (2001). 
I samtliga studerade texter finns implicit eller explicit en vilja att ha svar på frågan - varför befinner sig skolan i en kris? Man kan notera att såväl Ohrlander som Enkvist utgår från personligt erfarande av skolan när de börjar ställa frågor till det förflutna. ${ }^{84}$ När sedan författarna i en slags historisk "fascination" söker sig tillbaka till det förflutna är svaret på frågan om vad som orsakat skolkrisen i hög grad Skolkommissionen. Författarna gör sedan fördjupande tolkande nedslag för att precisera vad som mer specifikt i Skolkommissionens förslag utgör problemet. Med stöd i denna tolkning ges sedan en orienterande normativ tolkning om hur skolan bör utvecklas. Att använda historia på detta sätt är inget unikt för kritiska skoldebattörer, utan snarare närmast något generellt mänskligt enligt Rüsen. Vi kan exempelvis se att Skolkommissionen via Alva Myrdal och Stellan Arvidson också använde det förflutna på ett principiellt snarlikt sätt. Kommissionen var exempelvis tidigt ute med att med att anklaga den tidigare undervisningen för att vara "medeltida" och att för att skapa en modern demokratisk skola måste de medeltida inslagen i form av katederundervisning rensas ur från skolan. Detta kan ses som ett "narrativt rättfärdigande" för att genomföra reformerna.

I de tre analyserade texterna framträder åtminstone två narrativa huvudnivåer, nationens och skolans. ${ }^{85}$ Även om skolan hos samtliga författare ligger i fokus finns det ett stark historiskt nationellt narrativ invävt i historien om skolan vilket leder till att skolans kris också är nationens kris. Sensmoralen blir därmed att om skolan fallerar, fallerar nationen.

Den övergripande nivån handlar alltså om den nationella utvecklingen under efterkrigstiden och här ställs kommissionen, liksom t ex "68-generationen" till svars för problem i dagens samhälle. Wiklund som studerat bilden av "68" visar också hur 68-rörelsen blir en del av en större nationell berättelse där dess kritiker talar om till exempel det "galna kvartseklet" då Sverige åsamkades stor skada värderingsmässigt. ${ }^{86}$ Hos framförallt Enkvist är det tydligt. Det är en nationell kris (inte enbart en skolkris) att elevernas kunskaper har sjunkit. Retoriskt inleds Enkvist text med ett "När nu Sverige har sjunkit i PISA-jämförelserna". Vi får också snart veta att kommissionen har en central roll här och att den var del av en "kulturrevolution light". ${ }^{87}$ I den högerpopulistiska bloggaren Julia Caesars texter är det nationella inslaget än tydligare; hon talar om att nationens undergång och islamiseringen av Sverige kan relateras till kommissionens radikala brott med svenska traditioner. Ohrlander skriver också in kommissionen i en större nationell krisberättelse, där framförallt brottet med gamla seder och bruk länkas till kommissionen och dess tidsanda. Normbrottet innebar att "sociala trafikregler, som utformats under tusentals år" ${ }^{88} \mathrm{i}$ bondesamhället bröts. Skolkommissionen och dess samtid ställs här till svars för något mer än bara en skolkris.

84 Ohrlander (1981), 11. Enkvist (2016), baksidestext. Jämför med Hans Olofsson, Historia på högstadiet (Karlstad: Karlstad University Press, 2019) och resonemangen om erfarande och tolkning av det förflutna.

85 Det är också faktiskt möjligt att se en tredje nivå, den personliga. Som nämnts får vi biografisk information om Enkvists och Ohrlanders erfarenhet av svenska skolan.

86 Wiklund (2012).

87 Enkvist (2016), 7.

88 Ohrlander (1981), 113. 
Nationen är ett tema i samtliga texter, men det finns betydande skillnader. Enkvist kan sägas skriva in sig i en tradition där en generell borgerlig meritokratisk kritik mot att jämlikhet har prioriterats på bekostnad av kunskap är central. Detta perspektiv återfinns exempelvis i den amerikanska diskussionen om "excellent movement" och nationens karaktär. ${ }^{89}$ I Enkvists text förs kritiska generella resonemang om problemet med frånvaron av meritokrati i utbildningssystemet via referenser till den brittiska utbildningssociologen och socialdemokraten Michael Young ${ }^{90}$, samt Torsten Husén. Exempelvis noteras att Husén var "negativ till skolans meritokratiska effekt".91

Ohrlander skriver snarare in sig i en mer "folklig" vänsterinriktad nationell maktkritisk populärvetenskaplig historieskrivning som växte sig stark under 1960- och 1970-talet både inom den vetenskapliga historiografin och inom den populärvetenskapliga historieskrivningen. ${ }^{92}$ Ohrlander återkommer till exempel till Myrdals och Arvidsons avskildhet från folket och han påpekar att arbetarklassen måste ha traditionell kunskap för att kunna utmana den "den härskande klassen". Det finns också i hans sista bok ett betydande inslag av "folkhjältar" i form av vanliga lärare som vill förändra skolan i strid mot byråkrater, kapitalister och det pedagogiska etablissemanget. Vidare finns det även en genomgående kritik mot de "nyfeodala" strömningar som innebar att kulturradikalismen tog plats i statsförvaltningen och bröt med gamla bondetraditioner. Skolkommissionen, Arvidson och Myrdal blir centrala representanter för denna utveckling.

Slutligen kan man säga att Caesars narrativ kopplas till ett främlingsfientligt och invandrarkritiskt narrativ som lånar drag av såväl folklig historieskrivning som en mer traditionell konservativ syn på historia och samhälle, detta invandringskritiska narrativ finns inte hos Ohrlander och Enkvist.

Kommissionen skrivs också in i ett skolnarrativ om en krisande skola orsakad av naiva progressivister och ett kunskapsfientligt pedagogiskt etablissemang, ett narrativ som har internationella motsvarigheter. ${ }^{93}$ Författarna pekar på ett antal avgörande brister i samtiden som kan kopplas till historiska beslut, därmed finns tydliga drag av en kritisk berättelse i narrativen. Men även här finns nyanser och framförallt ger Ohrlander en mångkausal förklaringsmodell till skolkrisen. I relation till framförallt Enkvist tillkommer här också en betydande marknadskritisk förklaringsmodell.

Narrativen har alltså några grunddrag gemensamt. Kommissionen och centrala personer skuldbeläggs, detta görs genom att på olika sätt lyfta fram aspekter av skolan, samhället och nationen som försvann i och med kommissionen. Det finns också visioner om framtiden där kunskaper, moral och traditioner betonas. Berättelsernas sensmoral är sammanfattningsvis framförallt när det gäller Ohrlander och Enkvist att uppgivandet av traditionell undervisning och kunskap under 1940-talet i förlängningen kom att leda till den skolkris vi har idag.

Det finns några grunddrag gällande hur aktörerna karaktäriserar narrativen, om än med olika betoning. Det är huvudsakligen en aktörs- och idédriven utveckling läsaren får ta del av. I framförallt Myrdal och Arvidson "inkarneras" de centrala vi-

89 Symcox (2002). Notera att denna kritik inte innebär kritik mot att utbildning är tillgänglig för alla.

90 Envkist (2016), 217.

91 Envkist (2016), 228.

92 Burke (2007); Zander (2001).

93 Evans (2012); Malmström (2017). 
sionerna och samtida idéerna om kulturradikalism och förkastande av traditioner. Snarare än komplexa orsaksförklaringar personifieras historiens utveckling. ${ }^{94}$

Analyser av historiska "skolnarrativ" i Sverige har tidigare indikerat ett slags monumentalistiskt historieskrivande där exempelvis folkskolans införande beskrivs i ett romantiskt skimmer. ${ }^{95}$ Folkskolan blir här en del av en upplevd svensk framgångssaga och ett minne värt att fira. I narrativet om en krisande skola och en krisande nation blir Skolkommissionen däremot i vår nära samtid snarare ett Poltava, och Alva Myrdal och Stellan Arvidson (något tillspetsat) en Carl Olof Cronstedt (befälhavaren på Sveaborg som gav upp utan strid 1808 vilket i förlängningen innebar att Sverige förlorade Finland). Även om det finns inslag av ett "antikvariskt" historieskrivande då det "förflutna bör återupprättas" är det selektiva delar av det förflutna som ska återupprättas. Till det förflutna räknas naturligtvis inte perioden 1948-2011, utan det är närmast föreställningar om en mytisk guldålder där traditionell kunskap, respekt för traditioner och strävsamhet tänktes råda före den modernistiska välfärdsstatens införande. ${ }^{96}$

Texternas karaktär och budskap bör förstås i relation till sin samtid. Ohrlanders texter är delvis pionjärverk men speglar också samtidens kritik mot byråkrati och en växande kritik mot aspekter av folkhemmet som sedan till exempel Hirdmans studie Att lägga livet till rätta (1989/2010) exploaterar. ${ }^{97}$ Enkvists bok kan också ses i relation till denna folkhemskritiska rörelse, men här fångas också en mer grundläggande diskussion om meritokrati och jämlikhet upp. Även om narrativen ställer skolan till svars, finns det mer övergripande aspekter av den svenska samhällsmodellen som kritiseras via Skolkommissionen. Det moderna projektet ställs också till svars för upplevd normlöshet, traditionsbrytande och bristande meritokratiska principer. Skolkommissionen blir här en tacksam historisk symbol då samhällsreformatorer som Alva Myrdal och Stellan Arvidson inte bara sysslade med skolreformer utan också ville omstöpa hela samhället i en modernistisk och socialistisk riktning.

\footnotetext{
94 Jämför med Behan C McCullagh 1998. The Truth of History (New York: Routledge, 1998).

95 Larsson ( 2012).

96 Det är rimligt att kritisk narrativ till dagens marknadsstyrda skola också innehåller tankar om att en "guldålder" fanns före införandet av friskolor och valfrihet.

97 Hirdman (2010).
} 


\section{Käll- och litteraturförteckning Otryckta källor}

Skolkommissionen 1946-1952. Riksarkivet.

AI V2

FIII V1

\section{Digitala källor}

Caesar, Julia. "Skoldrömmar som brast del 2"

https://juliacaesar.blog/2018/03/05/skoldrommen-som-brast-del-2/

(Accessed August 5, 2018).

"Svenska skolans sjunkande elevresultat"

http://snaphanen.dk/2012/11/06/svenska-skolans-sjunkande-elevresultat/

(Accessed August 5, 2018).

\section{Litteratur}

Almgren, Birgitta. Dröm och verklighet. Stockholm: Carlsson, 2016.

Arvidson, Stellan. Skolreformen. Lund: Gleerups, 1948.

Arvidson, Stellan. Skolan vi skall få. Lund: Gleerups, 1950.

Berger, Stefan och Christoph Conrad. The Past as History. Basingstoke: Palgrave, 2015.

Biesta, Gert. "Pragmatising the Curriculum: Bringing Knowledge Back Into the Curriculum Conversation, but via Pragmatism." Curriculum Journal 25, no. 1 (2014), 29-49.

Boëthius, Maria Pia. På heder och samvete. Stockholm: Ordfront, 1999.

Bryman, Alan. Social Research Methods. Oxford: Oxford University press, 2012.

Burke, Peter. "History of Events and the revival of Narrative." I New Perspective on Historical Writing, red. Peter Burke. Cambridge: Wiley, 1993.

Burke, Peter. Vad är kulturhistoria? Eslöv: Symposium, 2007.

Carretero, Mario. Constructing Patriotism. Charlotte: IAP, 2011.

Cubitt, Geoffrey. "History of memory." In Debating New Approaches to History, red. Marek Tamm och Peter Burke, 127-142. New York: Bloomsbury, 2019.

Depaepe, Marc et al. Order in Progress: Everyday Education in Primary Schools -Belgium 1880 -1970. Leuven: Leuven University Press, 2000.

Enkvist, Inger. De svenska skolreformerna 1962-1985 och personerna bakom dem. Möklinta: Gidlunds, 2016.

Esaiasson, Peter, Mikael Gilljam, Henrik Oscarsson och Lena Wängnerud. Metodpraktikan: Konsten att studera samhälle, individ och marknad. Stockholm: Norstedts juridik, 2007.

Evans, Ronald. The Hope for American School Reform. New York: Palgrave Macmillian, 2012.

Evans, Ronald. The Social Studies Wars: What Should We Teach the Children? New York: Teachers College Press, 2004.

Frykman, Jonas. Ljusande framtid. Lund: Historiska media, 2014.

Frykman, Jonas. "Skolan måste lära barnen vanligt hyfs." Expressen, 20 december, 2013.

Gudmundson, Per. "Svenska skolan skulle förbereda för socialismen." Svenska Dagbladet, 29 oktober, 2016. 
Henrekson, Magnus, Inger Enkvist, Ingvar Martin och Ingrid Wållgren. Kunskapssynen och pedagogiken. Stockholm: Dialogos, 2017.

Hirdman, Yvonne. Att lägga livet till rätta. Stockholm: Carlsson, 2010.

Hobsbawm, Eric. Massproducerade traditioner. Lund: Arkiv förlag, 2002.

Iggers, Georg G. Historiography in the Twentieth Century: From Scientific Objectivity to the Postmodern Challenge. Middletown: Wesleyan, 2005.

Isling, Åke. Grundskolan för allmänmänsklig kompetens. Stockholm: Sober Förlags $\mathrm{AB}, 1984$.

Johansson, Roger. Kampen om historien, Ådalen 1931: Sociala konflikter, historiemedvetande och historiebruk 1931-2000. Lund: Hjalmarson \& Högberg, 2001.

Karlsson, Klas Göran. "Historia, historiedidaktik och historiekultur: Teori och perspektiv." I Historien är närvarande: Historiedidaktik som teori och tillämpning, red. Klas Göran Karlsson och Ulf Zander, 13-89 Lund: Studentlitteratur, 2014.

Koselleck, Reinhart. Erfarenhet, tid och historia. Uddevalla: Daidalos, 2004.

Larsson, Esbjörn. "On the Use and Abuse of History of Education: Different uses of educational history in Sweden." I Knowledge, Politics and the History of Education. Münster: LIT verlag, 2012.

Lindesjö, Bo och Ulf P. Lundgren. Utbildningsreformer och politisk styrning. Stockholm: HLS Förslag, 2006.

Ludvigsson, Maria. "Det var ni som svek arbetarbarnen.” Svenska Dagbladet, 25 januari, 2018.

Lundahl, Christian. Viljan att veta vad andra vet. Stockholm: Arbetslivsinstitutet, 2006.

Lundgren, Ulf P. Att organisera omvärlden. Stockholm: Utbildningsförlaget, 1989.

Malmström, Martin. Synen på skrivande: Föreställningar om skrivande i mediadebatter och gymnasieskolans läroplaner. Lund: Studies in Educational Science Lund University, 2017.

McCullagh, Behan C. The Truth of History. New York: Routledge, 1998.

Nietzsche, Friedrich. Om historiens nytta och skada. Stockholm: Norstedts, 1998.

Ohrlander, Gunnar. Kunskap i skolan. Stockholm: P.A Nordstedts \& Söners Förlag, 1981.

Ohrlander, Gunnar. Den gudarna älskar. Sundbyberg: Optimal Förlag, 2009.

Olofsson, Hans. Historia på högstadiet. Karlstad: Karlstad University press, 2019.

Orrenius, Niklas, "Om mötet med Julia Ceasar." Dagens Nyheter, 5 september, 2015.

Persson, Sofia. Läraryrkets uppkomst och förändring. Göteborg: Göteborg Studies in Sociology, 2008.

Richardson, Gunnar. Drömmen om en ny skola. Stockholm: Liber, 1983.

Richardson, Gunnar. Svensk skolpolitik 1940-1945. Stockholm: Liber, 1978.

Rüsen, Jörn. Berättande och förnuft. Göteborg: Daidalos, 2004.

Röhrs, Herman och Volker Lenhart, red. Progressive Education Across the Continents. Wien: Peter Lang, 1995.

Salomon, Kim. "Den kulturella vändningens provokationer." Scandia 75 no. 1 (2009).

Samuelsson, Johan. "Ämnesprofessionalitet under omförhandling: Exemplet historielärarna kring 1940-1965." Didaktikens forum, no. 3 (2008).

Samuelsson, Johan och Christin Olin-Scheller. Teachers in the Borderland of Elementary School, Grammar School and Comprehensive School: Teachers on Teaching in the 1940s NOFA 6 - Nordic conference on school subjects, University of Southern Denmark, Odense, $29^{\text {th }}-31^{\text {st }}$ of May 2017. 
SOU 1948:27. 1946 års skolkommissions betänkande. Stockholm: Häggströms.

SOU 1974:53. Skolans arbetsmiljö. Stockholm: Allmänna förlaget.

SOU1992:94. Skola för bildning. Stockholm: Nordstedts.

Sundeen, Johan. 68-kyrkan. Stockholm: Bladh by Bladh, 2017.

Symcox, Linda. Whose History? New York: Teacher College Press, 2002.

Waldow, Florian. Utbildningspolitik, ekonomi och internationella utbildningstrender $i$ Sverige 1930-2000. Stockholm: Stockholms universitets förlag, 2013.

Wiklund, Martin. Historia som domstol. Nora: Nya Doxa AB, 2012.

White, Hayden. Metahistory: The Historical Imagination in Nineteenth Century Europe. Baltimore: Johns Hopkins University Press, 1975.

Yamasaki, Yoko."Introduction: Progressivism, New Education, and cultural encounter". I Educational Progressivism, Cultural Encounters and Reform in Japan. London: Routledge, 2018.

Yin, Robert. Case Study Research: Design and Methods. London: Sage, 2014.

Zander, Ulf. Fornstora dagar, moderna tider. Lund: Nordic Academic Press, 2001.

Zilversmith, Arthur. Changing Schools: Progressive Education, Theory and Practice 1930-1960. Chicago: The University of Chicago Press, 1993.

Ödman, Per Johan Kontrasternas spel. Del 2. Stockholm: Norstedts, 1995.

Östling, Johan. Nazismens sensmoral: Svenska erfarenheter i andra världskrigets efterdyning. Stockholm: Atlantis, 2008. 